\title{
Geospatial Analysis of Exhibition Centers
}

\section{Geoprostorová analýza veletržních areálů}

Lenka Štěpánková, xastepankoval@stud.fa.vutbr.cz

Ústav urbanismu, Fakulta architektury, Vysoké učení technické v Brně školitel: doc. Ing. arch. Maxmilián Wittmann, Ph.D.

\begin{abstract}
The European exhibition centres may show some unique features but they also have many things in common. Their typical qualities can be identified using the spatial analysis. The metod described in this paper is devised to exploit the data available on internet and to create the visual output based on the data. Such analysis can be used to examine the size and structure of the venues as well as their position within the cities. The possible further use of the metod in urban research is indicated eventually.
\end{abstract}

KEYWORDS: fairs; urban research; spatial analysis; exhibition centres; european cities

ABSTRAKT: Veletržní a výstavní areály v Evropě mají v řadě případů unikátní charakteristiky i historii, současně však vykazují také mnoho společných znaků. Jako výchozí metoda identifikace obecných rysů může sloužit geoprostorová analýza. Lze ji využít $\mathrm{k}$ analýze pozice areálů v rámci měst, ke zkoumání zákonitostí historického vývoje, a především ke srovnání prostorových nároků, urbanistické struktury a vnitřního členění areálů. Zvolený postup kombinuje využití oborových statistik a volně dostupných mapových podkladů.

KLÍČOVÁ SLOVA: výstavní areály; výstaviště; evropská města; prostorová analýza

\section{Úvod}

S pronikáním informačních technologií do všech oblastí každodenního života se stále 
zvětšuje objem dat, která jsou volně k dispozici prostřednictvím internetu. Smyslem tohoto př́spěvku je názorně ukázat, jak mohou být tato data využita ke zkoumání urbánních jevů a struktur. Pilotní analýza se týká veletržních areálů a spočívá ve shromáždění potřebných údajů o vybraných veletržních areálech a o městech, ve kterých se tyto areály nacházejí, přičemž důležitou roli hraje také výběr konkrétních měst a areálů pro analýzu. Následujícím krokem je vizualizace velikosti areálů, jejich vztahu a poměru k centrální oblasti města. Poznatky z provedené analýzy slouží následně k pojmenování výhod dané metody a k identifikaci problematických míst.

\section{Výběr objektů}

Výchozím zdrojem pro výběr objektů pro průzkum nebo analýzu mohou být oficiální stránky institucí a jimi publikované oborové statistiky. Tato data mají relativně dobrou vypovídací schopnost, protože jsou shromaždována vždy konkrétní institucí podle jednotné metodiky. $\mathrm{V}$ př́padě veletržních areálů lze takto porovnávat auditovaná data týkající se návštěvnosti, počtu vystavujících firem nebo celkové výstavní plochy. Zásadní informace z oboru lze najít na stránkách následujících institucí: UFI - The Global Association of the Exhibition Industry (původně Union des Foires Internationales), EEIA - The European Exhibition Industry Alliance, BIE - Bureau International des Expositions, EMECA - European Major Exhibition Centres Association. Pilotní analýzu jsem se rozhodla provést s údaji o areálech všech provozovatelů sdružených v asociaci EMECA, které jako celek představují reprezentativní vzorek úspěšně fungujících veletržních a výstavních areálů napříč Evropou. Výhodou je, že tyto areály vesměs mají vlastní webové stránky, které lze využít jako doplňkový zdroj informací o konkrétních lokalitách.

\section{Zdroje dat}

Jako zdroj prostorových dat jsou využitelné mapové podklady dostupné online. V závislosti na zvoleném tématu a předpokládaném zpo̊sobu jeho zpracování lze využít bud' mapy společnosti Google (https://maps.google.cz/ nebo https://maps.google. com), nebo společnosti Seznam (https://mapy.cz/). Další alternativou jsou otevřené mapy vytvářené a editované komunitou přispěvatelů: OpenStreetMap (https://www. openstreetmap.org/). V úvahu přichází také využití webové stránky Cadmapper (https://cadmapper.com/), která nabízí ke stažení data ve formátu dwg pocházející z veřejně dostupných zdrojů (zmíněný OpenStreetMap, NASA, USGS). Menší soubory jsou po registraci ke stažení zdarma, větší objemy dat (respektive území větší než $1 \mathrm{~km}^{2}$ ) jsou $\mathrm{k}$ dispozici předplatitelům. Data jsou dostupná v geodetických souřadnicích.

Velmi zjednodušeně lze tvrdit, že mapy společnosti Google mají nejlepší pokrytí 
a zpracování v celosvětovém měřítku, mapy společnosti Seznam jsou přesnější nad územím České republiky a OpenStreetMaps jako otevřená platforma nabízejí nejvíce možností zpracování. Pro svůj projekt týkající se veletržních areálů jsem z tohoto důvodu zvolila využití map společnosti Google. Před shromažd’ováním dat je vždy nutné prověřit, zda aktuálně platná verze licenčních podmínek umožňuje využití mapových podkladů $\mathrm{k}$ danému účelu (1).

Základní demografické údaje (počet obyvatel ve městech a obcích) lze v rámci České republiky snadno získat z oficiálních zdrojů, konkrétně z materiálů Českého statistického úřadu publikovaných online. $V$ širším měřítku v rámci Evropy by teoreticky bylo možné získat data obdobně z webu jednotlivých národních institucí, problém zde představuje nutnost vyhledávat v množství jazykových mutací. Místo toho je možné poměrně jednoduchým způsobem získat potřebné údaje $z$ jiného internetového zdroje, je však nutné je velmi obezřetně interpretovat, protože nevychází z jednotné metodiky a mohou zde být značné rozdíly v přesnosti. Ke všem městům zahrnutým v průzkumu jsem na webu (https://wikipedia.com) vyhledala udávaný počet obyvatel (2) a tento údaj jsem použila pro schematické zatřídění měst do jedné z velikostních kategorií takto: města do 0,5 milionu obyvatel, 0,5-1 milion obyvatel, 1-2 miliony obyvatel a velkoměsta s počtem obyvatel nad 2 miliony.

\section{Způsob zpracování}

Zakreslení rozlohy areálů a jejich polohy vůči centrální oblasti města jsem zpracovávala nad podložením mapovými a ortofotografickými snímky. Tam, kde z těchto podkladů nebylo vymezení území zcela zřejmé, jsem jako doplňkový zdroj informací použila orientační plánky dané lokality z webové stránky provozovatele. Výsledkem zpracování je soubor dwg s křivkami reprezentujícími jednotlivé areály a s centrálními oblastmi měst schematicky vyznačenými formou kružnic. Podkladové snímky a geometrie jsou uložené v samostatných hladinách, pojmenovaných podle měst. Tato struktura souboru umožňuje jednoduše vytvářet různé vizuální výstupy. Jako ukázku dalšího možného rozšíření jsem v relevantních případech ke křivkám reprezentujícím areál výstaviště doplnila piktogram letiště. Stejným způsobem je možné doplňovat schematicky symboly jiných dopravních staveb (letiště, dálnice), významných veřejných staveb, historických areálů výstav Expo a podobně.

\section{Výsledky analýzy veletržních areálů}

V popisovaném př́ípadě se jedná o vzorek př́liš malý na to, aby bylo možné interpretovat data statistickými metodami. Je však dostatečný na zvýraznění zajímavých fenoménů, které lze následně blíž zkoumat - např́iklad poměru velikosti areálu k velikosti města nebo aglomerace (Moskva, Hannover). Opakujícím se jevem je existen- 
ce více areálů v rámci jednoho města, přičemž blíže historickému jádru se nacházejí vždy menší a starší areály (Paříž, Barcelona, Milán). Někdy je důvodem zdvojení výstavišt přítomnost bývalých areálů výstav Expo, pozůstatků po světových výstavách (Barcelona, Milán, Brusel). Lze také porovnávat areály v historické centrální poloze s areály dislokovanými na periferii měst ve vazbě na dopravní infrastrukturu (3).

\section{Výhody metody a její možné využití}

Popisovanou metodu lze použít $\mathrm{k}$ analýze jakýchkoliv jednoznačně vizuálně identifikovatelných urbánních struktur, jako jsou např́klad dopravní stavby, nákupní galerie, logistické a výrobní areály nebo př́rodní prvky v městské struktuře. Lze ji také použít k porovnávání měřítek urbanistických struktur, např́klad různých typů residenční výstavby. Hlavní výhoda spočíá v možnosti porovnávat prakticky libovolné množství dat, která jsou navíc snadno dostupná a mají jednotnou formu.

\section{Problémy a slabá místa}

Hlavní slabina metody spočívá právě v nutnosti vizuální interpretace podkladů. Konkrétně veletržní areály lze jednoduše odlišit od rezidenční zástavby, může však být problematické rozeznat je od sousedících objektů podobného měřítka, jako jsou hotely, sportovní haly nebo nákupní galerie. Podobná situace může nastat i u jiného typu zkoumaných objektů. $\mathrm{V}$ takových př́padech je vhodné použít doplňkový zdroj informací. U některých typů dat získaných z internetu je třeba pečlivě zvážit, jaká je jejich míra přesnosti, a zvolit dostatečně robustní postup zpracování, aby případné nepřesnosti nezkreslovaly výsledek.

\section{Prameny a poznámky}

1. Obecně platí, že společnosti Google a Seznam umožňují využití svých podkladů k nekomerčním účelům. Nutné je uvedení zdroje, není možná změna vlastního obsahu, nebo vytváření alternativních mapových podkladů. Změnou obsahu je myšleno např́ílad odstranění vodoznaku z ortofotografií, nebo změna barevného podání. Zdroj: Smluvní podmínky upravující možnosti využití mapových podkladů Google, dostupné z: https://www.google.com/intl/cs_cz/help/terms_ maps.html, [cit. 2017-08-11].

2. Vzhledem $\mathrm{k}$ historickému vývoji, a jím dané podobné urbanistické struktuře evropských měst, lze údaj o počtu obyvatel použít také jako údaj vypovídající o velikosti centrální ćásti - historickém jádru. Při nesourodém vzorku, zahrnujícím např́iklad americká nebo asijská města, př́ípadně města zakládaná v průběhu 20. Století, by bylo nutné metodu vhodným způsobem upravit. 
3. Důvody, proč některé areály zůstaly ve své v centrální poloze a jiné se přesunuly na periferii, vysvětluje ve své práci Vermeulen (2013) teorií závislosti na zvolené cestě a ilustruje je na př́kladu Frankfurtu a Mnichova.

VERMEULEN, Rick. Pursuing the Peripheral Path? A Path-Dependent Analysis of the Frankfurt and Munich Fairs. European Planning Studies [online]. Routledge, 2013, [cit. 2017-08-11]. DOI: 10.1080/09654313.2013.867318. ISSN 0965-4313.

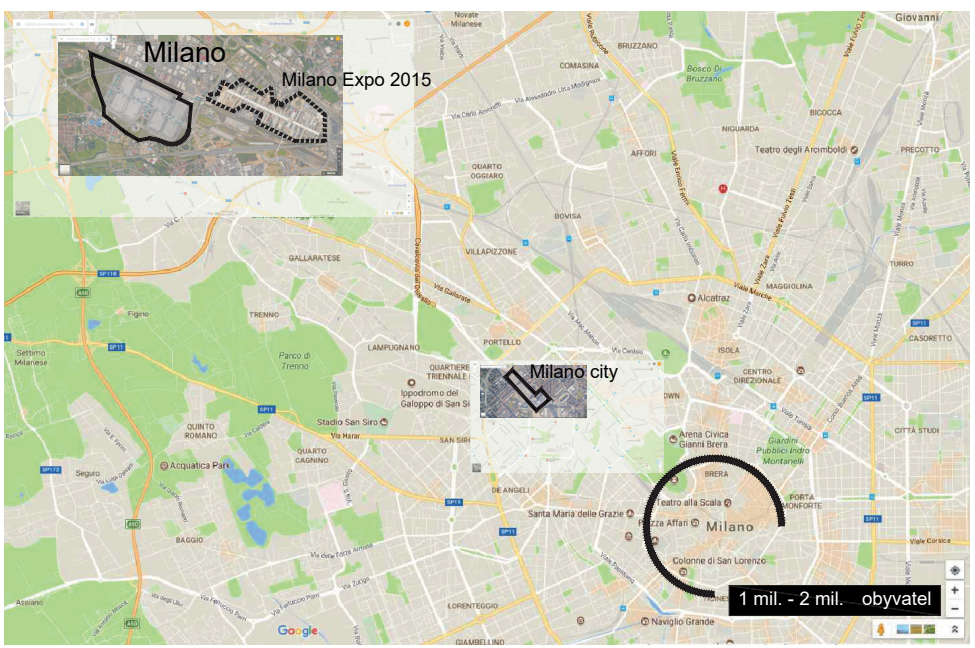

Obr. 1. Tvorba geometrie nad vloženými podklady
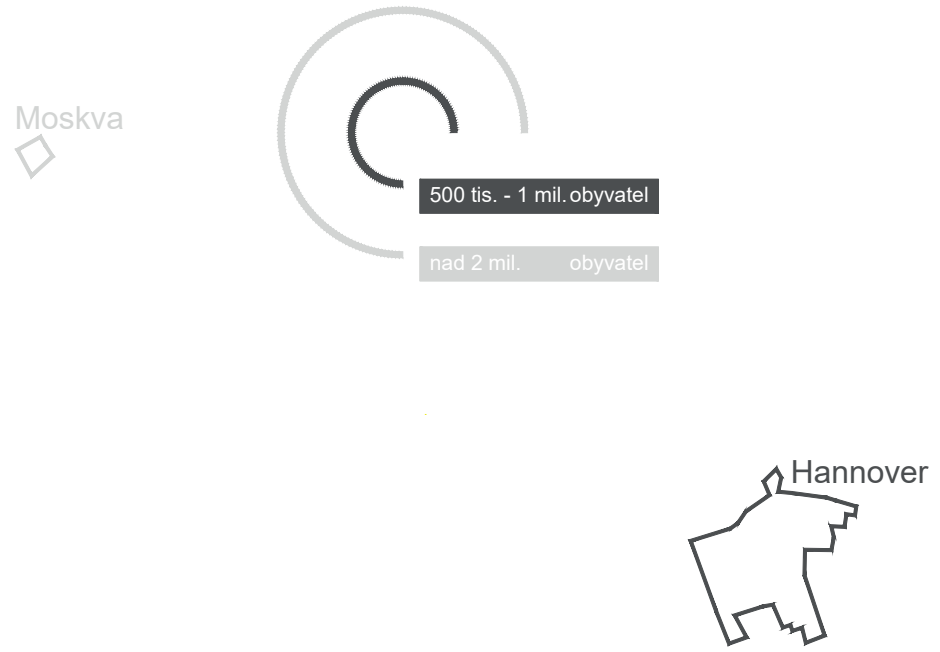

Obr. 2. Srovnání poměru a vztahu výstavního areálu k centrální části města (Moskva, Hannover) 

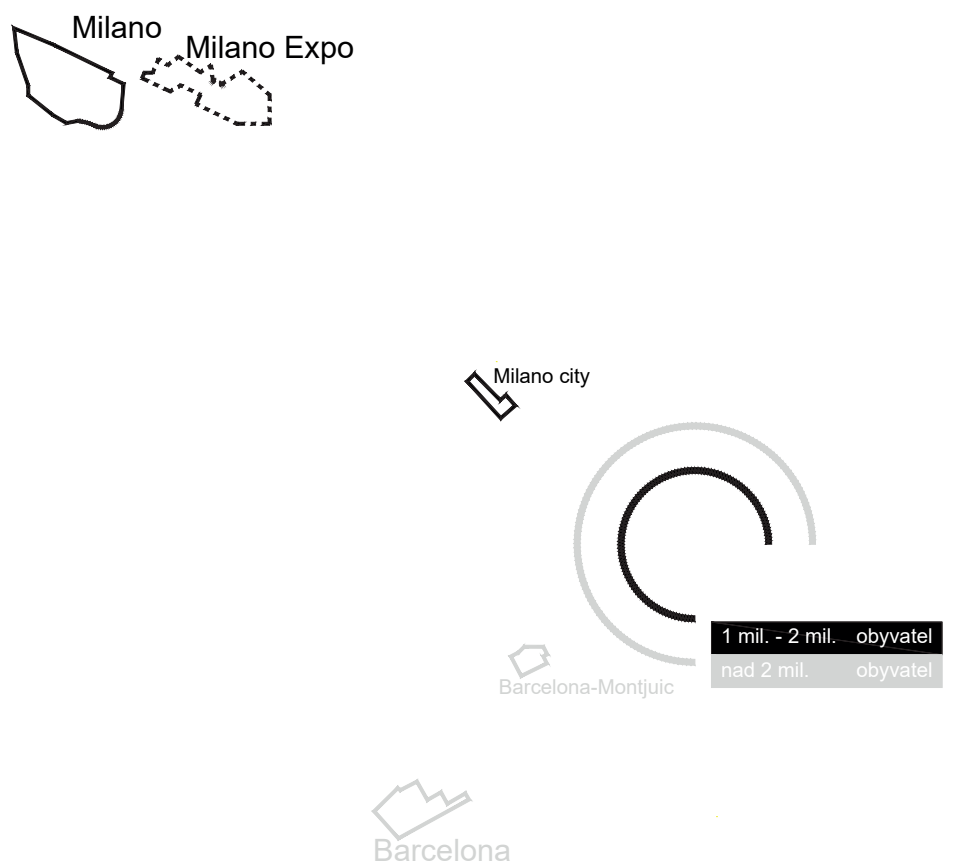

Obr. 3. Moderní areály mají větší rozlohu a jsou vzdálenější od centra města (Barcelona, Milán)

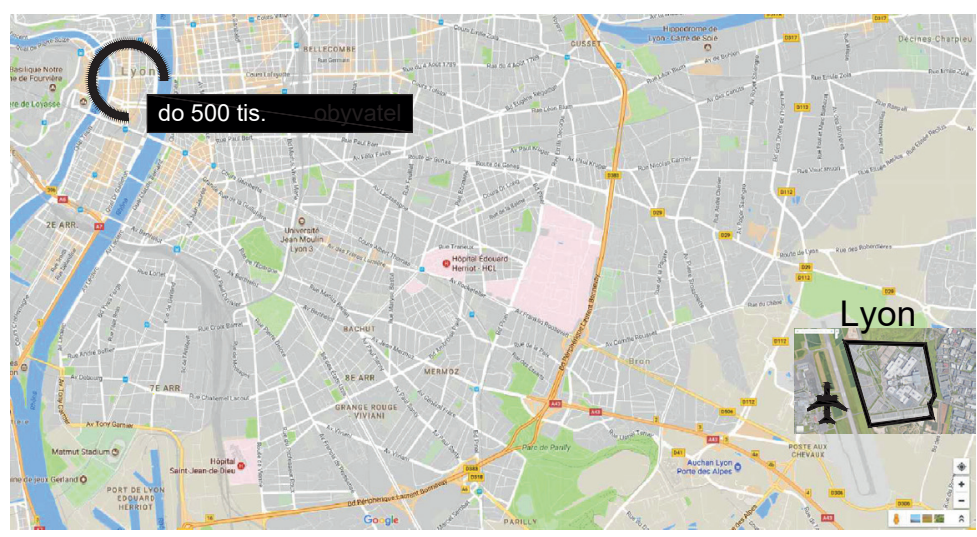

Obr. 4. Prvky dopravní infrastruktury jsou snadno vizuálně identifikovatelné 